This is the accepted version of an article published as

Foster, M. John and Watkins-Mathys, Lorraine (2020) Examining conditions for successful entrepreneurship in China's firms. International Journal of Entrepreneurship and Innovation Management, 24(4/5), pp. 339357. ISSN (print) 1368-275X, and available at https://doi.org/10.1504/IJEIM.2020.108249 


\title{
Examining conditions for successful entrepreneurship in China's firms
}

\author{
M J Foster* \\ Emeritus Fellow \\ Kingston Business School \\ Kingston Upon Thames, KT2 7LB, UK \\ E-mail: foster@kingston.ac.uk \\ *Corresponding author \\ Lorraine Watkins-Mathys \\ Former Dean \\ Faculty of Design, Media \& Management \\ Bucks New University \\ High Wycombe, HP11 4JZ \\ E-mail: watkinsmathys@yahoo.co.uk
}

\begin{abstract}
We examine the question of what factors might be likely to increase the probability of success for entrepreneurial activity by FIEs and domestic firms in China. We first examine the possibility of there being a distinct and separate notion of Chinese entrepreneurship but find that unlikely. The issue then becomes what contextual factors may be necessary to enable entrepreneurial activity in China to flourish and we locate four such factors. We acknowledge that our posited set of necessary factors is probably not a sufficient set but they are at the minimum a useful starting point.
\end{abstract}

Keywords: entrepreneurship, China, FDI, domestic investments, higher added value, context 


\section{Introduction}

Inward FDI to China grew by a factor of almost 50 between 1990 and 2015 and, although recent figures suggest something of a dip in 2016, FDI continues to be significant, as Table 1 illustrates. It has been an important driver for the PRC economy and recent pronouncements by the PRC government suggest they believe it will continue to play an important role. Li (2013) reports such sentiments and adds that, in the wake of the $3^{\text {rd }}$ Plenary Session of its $18^{\text {th }}$ Central Committee meeting, in November 2013, the central hierarchy of the Party pledged to better regulate FDI processes to make it more attractive for potential foreign investors to invest, especially for investment in more specialised units such as $R \& D$ centres. Time alone will determine how well founded such pledges were. In the meantime the official line is that they want FDI to continue, in order to thereby help to keep the Chinese economy booming, especially in higher added value (HAV) aspects of the economy. The HAV aspects of the economy are those firms or industries which add more value to their inputs in their processes than do other firms which operate on thinner margins.

Such pledges regarding an improved regulatory environment will presumably please current and potential foreign investors, especially since they have not always found life easy in terms of their investments in China. There have long been a range of difficulties experienced by foreign invested entities (FIEs), see for example Foster (2014). Moreover, Foster and Tseng (2014) report that FIEs operating in different industry sectors continue to have a range of problems of various kinds. The list of such problems includes but is not exhaustively covered by 'tricky', local partners (the cases of Danone and Hung To); difficulties with the supply chain (the Kingfisher and Tesco cases, for differing reasons); and, it is alleged, unreasonable pressure from the authorities, to hand over technological know-how to local firms (BASF and Siemens).

Table 1 - Inward FDI Flows into China and its GDP 1990-2015 (\$bn)

\begin{tabular}{|l|c|c|c|c|c|c|c|}
\hline Year & $\mathbf{1 9 9 0}$ & $\mathbf{1 9 9 5}$ & $\mathbf{2 0 0 0}$ & $\mathbf{2 0 0 5}$ & $\mathbf{2 0 0 6}$ & $\mathbf{2 0 0 7}$ & $\mathbf{2 0 0 8}$ \\
\hline GDP & 404.49 & 756.96 & 1192.14 & 2287.24 & 2793.18 & 3504.41 & 4547.28 \\
\hline IFDI & 3.5 & 37.5 & 40.8 & 72.4 & 72.7 & 83.5 & 108.3 \\
\hline Year & $\mathbf{2 0 0 9}$ & $\mathbf{2 0 1 0}$ & $\mathbf{2 0 1 1}$ & $\mathbf{2 0 1 2}$ & $\mathbf{2 0 1 3}$ & $\mathbf{2 0 1 4}$ & $\mathbf{2 0 1 5}$ \\
\hline GDP & 5105.46 & 5949.79 & 7314.14 & 8229.45 & 9181.20 & $10,430.59$ & $11,156.25$ \\
\hline IFDI & 95.0 & 114.7 & 124.0 & 121.1 & 123.9 & 128.5 & 174.4 \\
\hline
\end{tabular}

Source: Compiled from UNCTAD data available at http://unctadstat.unctad.org/

All of this suggests that there are opportunities for foreign investors but that they should not necessarily expect it all to be plain sailing. Within the FIE spectrum in China entrepreneurialism, entrepreneurship or so called intrapreneurship (the phenomenon when exhibited within an existing firm) can be expected to play an increasing role as FIEs work more in HAV businesses rather than more basic goods production. At the same time, the domestically invested sector of the economy may be expected to continue its significant growth, as may be inferred from the growth pattern of the Chinese economy as a whole, see Table 1 again.

Given this context, the question we explore in the rest of the paper is: what may be the key influences or factors which might be likely to increase the probability of success for entrepreneurship (or entrepreneurial activity) by FIEs and by domestic Chinese firms? 
Some might be tempted to suggest that the question should include the word 'ensure' setting the bar higher than the rather humbler ambition actually posited. The reason is simple. If one is serious and lives in the real world rather than some abstract academic world where perfection is feasible, there will inevitably be some disappointments, sometimes because of your own shortcomings but at others because forces beyond your control are exercised against you, by the host country government perhaps (see for example Foster, 2015). Another way of putting the same thing is that we should like ideally to find a sufficient set of conditions to ensure entrepreneurial success but a good start would be to identify an important set of necessary conditions.

If one wants to find such a necessary set of conditions regarding overall success of entrepreneurial activities, widely construed, we propose that one of the key things which one needs is entrepreneurial spirit, a point made even at the textbook level by Volberda et al (2011, Ch.14), allied to improved contextual factors (these will likely include better drafted and operated laws, improved protection of intellectual property rights (IPRs), a stable regulatory system, investment incentives like tax breaks etc). In considering entrepreneurship we think of it not only in the sense of the start-up phenomenon, which axiomatically would rule out moves made by large non-PRC MNCs, but also in the context of existing firms. If one reflects seriously, it becomes clear that one needs an entrepreneurial spirit in large companies, owned by whomever, if they are to develop new thinking, be it product innovation, process innovation, both of these or simply, but very importantly, skill at implementation in the new context. This is sometimes known as intrapreneurship, see Antoncic and Hisrich (2001), Drejer et al (2004). Because this debate is set in the context of business in the PRC it might be thought that what is going to be required is 'Chinese entrepreneurship' (CE) but does such a thing exist?

Our argument will be that in reality there is no separate phenomenon of CE but what may be needed are two things. First one does need entrepreneurship or an entrepreneurial spirit and it is clear that such is not always available in China, see for example Watkins-Mathys and Foster (2006). Secondly, to ensure entrepreneurship can operate successfully there should be an appropriately supportive context.

The rest of the paper comprises four more sections. The next section is essentially a literature review examining the ' $\mathrm{CE}$ or not' issue. After a brief discussion of the research methods used we move on to a section which looks at the contextual elements which may currently be deficient but are in fact necessary conditions for eventual success. The paper ends with a conclusion and associated recommendations.

\section{Defining entrepreneurship and Chinese entrepreneurship?}

If we are to determine whether there is such a thing as Chinese entrepreneurship and if so what its character might be, we must logically first ask what is entrepreneurship?

The Concise Oxford Dictionary (C.O.D.) (1976) defines entrepreneurship as "[the act of] undertaking a business or enterprise with chance of profit or loss". While this is at first sight fairly banal, one key thing to observe is the presence of the notion therein of risk, namely, the fact that it specifically admits the possibility of losses accruing to a business. 
Losses of course may arise for two different reasons. On the one hand it may simply be a result of commercial incompetence and this can occur in any type of business, the utterly mundane and the innovative. On the other hand there is that risk which arises because a business is engaging in some sort of innovative activity; they are taking steps into the unknown so to speak. This is what Schumpeter (1934) famously focussed on in his pre-war work, where he posited, in his analysis of the theory of trade cycles, that the innovations of entrepreneurs would be the main drivers of growth.

We see that the basic definition of entrepreneurship does not require there to be a genuinely innovative element but it is obvious, following Schumpeter's line, that one way in which a business may indeed fulfil its desire to access super-normal profits is via the development of an innovative product or concept. This is often seen as the placing of innovation at the centre of the entrepreneurial mix. However, a point worthy of note here is that in fact Schumpeter (1942) explicitly makes the point, complementary to the presence of innovation but also different, that having the ability to act on the opportunities which innovations create may be the key to success for a firm. As Schumpeter (1942, p.132) wrote:

To act with confidence beyond the range of familiar beacons and to overcome ... resistance [to significant change] requires aptitudes that are present in only a small fraction of the population and define the entrepreneurial type as well as the entrepreneurial function. This function does not essentially consist in either inventing anything or otherwise creating the conditions which the enterprise exploits. It consists in getting things done. (our emphasis)

This conjunction of elements leads to especial interest in what has been called 'technological entrepreneurship'. This idea includes the concepts of opportunity recognition, risk taking (Gartner, 1988; Olsson and Frey, 2002; Bygrave, 2004; Cunningham and Lischeron, 1991) and being able to translate the opportunity into entrepreneurial action (Cantillon, 2010; Knight, 1921; Say, 1850). Zhang et al (2008, p.735) summarise technological entrepreneurship as follows:

....technological entrepreneurship is of the character of opportunity entrepreneurship, it can be defined from the point of view of opportunity discovery and exploitation, namely "discover and exploit market opportunity of technology” (reference to Reynolds et al, 2002).

Especially in the arena of high-technology, or HAV, business, it seems fairly clear that many, not necessarily all but most, firms will seek to embrace this notion of technological entrepreneurship. In other words they will engage themselves in all aspects or phases of the entrepreneurial process. Similarly, in their attempt to describe a codifying framework for entrepreneurship research, Shane and Venkataraman (2000) emphasised the importance of using a wide enough lens to ensure one sees entrepreneurial opportunities as well as the actions of the would be entrepreneur(s).

Thus far nothing we have discussed has been in any way particular to any given country or economy. Hence, on balance, we take the view, based on the preceding discussion of the nature of entrepreneurship, that logical deduction leads one to the view that entrepreneurship is in fact the same wherever it occurs - an individual or small group of actors may make a more or less innovative pitch into some market, shouldering an inherent risk as they do so. 
One necessary internal condition for successful entrepreneurship in any firm, anywhere is a prevailing entrepreneurial spirit or entrepreneurial mindset (EM), which accepts and facilitates the entrepreneurial process, McGrath and MacMillan (2000), Kier et al (2014). According to McGrath and MacMillan (2000, Ch.1, p.1), the EM is "a way of thinking about your business that captures the benefits of uncertainty." They also claim (Ch.1, p.2) that an EM will be clearly in evidence when players in an organisation "start to act like habitual entrepreneurs." This means that such people are likely to have a go-getting, open minded approach, are tolerant of uncertainty and have cognitive adaptability as Haynie and Shepherd (2009) explain. So far so good but Kier et al (2014) also strike a note of caution to the effect that people must not singly or collectively get carried away with too much missionary zeal, so to speak. They found that some of the very aspects of an EM which can lead to success may also at times lead to keeping going with developmental projects when the prudent decision would be to stop; there can be an escalation of commitment to new or developmental projects beyond prudent limits which a more careful assessment of risk would allow. In other words, it is necessary at all times to maintain focus on the risks associated with a given project and if that risk is, or becomes, excessive to desist.

We now move on to the question of why there is a need to discuss the concept of CE, or whether that is actually so. Basically the argument is pragmatic: the phrase can be readily found in the context of work done in and around the wider sweep of entrepreneurship in China, albeit with no clear definition or description of the concept, see e.g. Carlisle and Flynn (2005), Yu and Stough (2006), Li and Matlay (2006), Kshetri (2007). Li and Matlay (2006) have as one of their objectives the setting of a 'tentative research agenda' for entrepreneurship and small business development in China but, as they concede (p.259), "research has so far failed to reflect the complexity and depth of this [as they see it] extraordinary phenomenon." Li et al (2012) suggest that CE does exist but then go on to argue that it has no single manifestation; rather there are many variants of Chinese entrepreneurship and these variants continue to evolve rapidly and to take on new forms. If such an animal were indeed to exist the question is "what would it comprise, what would it look like that might be different from that found elsewhere?"

At first reading, it seems that the article of Huang (2010) may offer a possible answer. He makes a distinction between what he suggests are two, differing types of entrepreneurship 'catch-up entrepreneurship' and 'frontier entrepreneurship'. Huang states (p.3 on-line) that, "Catch-up entrepreneurship engages in replicative activities - those activities that have been invented by others and they are now being copied and created at competitive costs. The vast majority of Chinese entrepreneurs are of the catch-up kind. Their main economic contribution is job creation, rather than making breakthroughs in science and technology [which are more likely to be the role of frontier entrepreneurship, authors' comment]." Huang goes on to say that much of this kind of replicative work is undertaken by small businesses in the rural areas of China. Hence, it is often unseen by external observers, albeit significant as a factor promoting the rural economy and providing employment there. In macroeconomic terms, it is what he calls frontier entrepreneurship which is likely to be a more important driver for the Chinese economy. However, neither of these sub-varieties of entrepreneurship are noted to have obvious features different from entrepreneurship elsewhere and hence the importance of the distinction lies in explaining location of occurrence within China rather than helping to identify a truly CE.

Finally in this part, we look at who those noted to be entrepreneurs in China are. Ahlstrom and Ding (2014) first make the point in their review that entrepreneurship and new venture 
creation have played an important role in that they have fuelled a significant proportion of China's growth over recent years. This is a factor shared, they argue, with other developing countries. As to who these entrepreneurs are, they are said to be relatively young and welleducated; Ahlstrom and Ding suggest that about 44 percent are in the 25-34 age group. However, as with other authors, they do not locate and specifically say what is special and different about the entrepreneurship of those in China compared with elsewhere in the world. Beyond these young dynamos are those who have made it into the super-rich bracket. They tend to be a little older, unsurprisingly one imagines, since it takes time for even the best new ideas to be leveraged to maximum revenue earning potential. Table 2 shows the ten richest entrepreneurs in China according to one CNBC report, Gilchrist (2018). Five of the ten listed are involved in the manufacture or use of electronic technologies, and another four are in the real estate/property development area. Other well-known self-made billionaires, just not quite as rich, include Liu Chuan Zhi, founder of Lenovo, the computer firm; and Zong Qing Hou, the founder and boss of Hangzhou Wahaha Group. Wahaha branded drinks include importantly water and 'tea soft drinks'. The latter are Chinese competitors to Coca Cola: the tea flavouring is almost incidental; they are basically sugary soft drinks, just as Coke is.

Table 2 China's Top Ten Entrepreneurs - according to CNBC MAKE IT

\begin{tabular}{|l|l|l|}
\hline $\begin{array}{l}\text { Entrepreneur's Name } \\
\text { (age, if known) }\end{array}$ & Company and product area & $\begin{array}{l}\text { Estimated wealth } \\
\text { in \$bn - 2018 }\end{array}$ \\
\hline MA HuaTeng (47) & $\begin{array}{l}\text { Tencent; internet service provider } \\
\text { plus on-line games and messaging }\end{array}$ & 41.8 \\
\hline MA Jack (54) & $\begin{array}{l}\text { Alibaba Group; e-commerce, now } \\
\text { global reach }\end{array}$ & 40.2 \\
\hline HUI Ka Yan (60) & $\begin{array}{l}\text { Evergrande Group; Real estate } \\
\text { development }\end{array}$ & 27.5 \\
\hline YANG HuiYan (f) & $\begin{array}{l}\text { Country Gardens Hldg. Co.; } \\
\text { property development; majority } \\
\text { shareholder }\end{array}$ & 20.7 \\
\hline WANG JianLin (64) & $\begin{array}{l}\text { Dalian Wanda Group; } \\
\text { conglomerate with luxury hotel } \\
\text { properties, commercial real estate } \\
\text { and e-commerce }\end{array}$ & 18.1 \\
\hline DING Lei & $\begin{array}{l}\text { NetEase; internet content and e- } \\
\text { commerce }\end{array}$ & 17.2 \\
\hline LI HeJun (51) & $\begin{array}{l}\text { Hanergy Holdings; solar power } \\
\text { technology and hydro generation }\end{array}$ & 15.5 \\
\hline LEI Jun (49) & $\begin{array}{l}\text { Xiaomi; main products smart } \\
\text { phones and apps for them }\end{array}$ & 15.2 \\
\hline ZHANG Tony & Co-founder of Tencent & 15.0 \\
\hline YAN JieHe & China Pacific Construction Group & 14.1 \\
\hline SOH & Ching & \\
\hline
\end{tabular}

Source: CNBC MAKE IT, $20^{\text {th }}$ February 2018

The question still remains then: 'what is CE?' The way in which an identifiably distinct CE might be said to occur probably lies in the fact that any entrepreneurial activity takes place in a context and contexts do differ, both in terms of social norms and institutional structures. More precisely, since the core theoretical proponents come from Europe and America, the question becomes what is different in China as compared with those places. Thus what may 
be special is how Chinese entrepreneurs (CEs) cope, or struggle to cope, with the special contextual factors which are the defining character of China, guo qing, about which we have written elsewhere (Tseng and Foster, 2006; Watkins-Mathys, 2015). This view of the special contextual challenge for China's entrepreneurs is supported by Ahlstrom and Ding (2014).

For many entrepreneurs, there is a technological component to their business and factors influencing the technological enterprise can be situated both inside and outside a firm's boundaries wherever it is located, but by extension in China, Zhang et al (2008). Among external factors affecting technology transfer in China, one might plausibly cite the following: economic clusters, notably STIPs (Science and Technology Industry Parks) and their effect on innovation (Porter, 1998); the role of universities as sources of knowledge in effecting knowledge transfer to organisations (Wang and $\mathrm{Lu}, 2007$ ); and the influence of government policy on technology transfer (Wang and Zhou, 1999). While these are selfevidently important influences on HAV firms in China, be they FIEs or domestic firms, they do not in themselves explain the success of or lack of success of entrepreneurship.

The internal factors contributing to entrepreneurial action (Gartner, 1988 and Bygrave, 2004) include the firm's internal resources and capabilities, which create value by successfully, commercialising technologies (Petti and Zhang, 2011). Allied to this, entrepreneurs' social networks may also play a role in opening doors in the value creating process (Klepper and Sleeper, 2005). This is widely stated to be of great importance in China and is often afforded its own special name of guanxi in China, see e.g. Tsang (1998). Such networks are, curiously, internal and external simultaneously: internal because they are particular to the given entrepreneur/s and their business; external because they necessarily stretch their arms outwards.

In her thesis, Cao (2009) identified the following list of key constraints for entrepreneurial activity based in SMEs in the PRC's electronics industry:

- Networking (as above)

- Availability of venture capital (VC)

- A weak pool of business savvy potential employees, even amongst graduates from whom one might have expected more.

As noted, she looked specifically at a sample of firms from the electronics industry but it seems entirely reasonable to conjecture that such factors will apply much more widely across the Chinese industrial canvas.

From a summative perspective, a plausible set of external factors to arise from our discussion thus far can be taken to be Cao's triple plus the broader regulatory framework experienced by firms in China, especially where those regulations may, in practice, differ for FIEs as compared to 'home' companies. Looking at firms from the inside, we have also identified the need for an entrepreneurial mindset, if entrepreneurship and intrapreneurship are to flourish.

\section{Research methods used}

In summary this paper is a piece of discursive research. Some might prefer a phrase such as 'exploratory, desk research, rooted in secondary data' but the meaning is clear. Therefore, the data used are essentially culled from secondary sources, including some insights from our own, prior, empirical work. The analysis comprises logical argumentation rooted in the 
secondary data base accessed and the outcomes are the result of what may be described as textual analytical sense-making, see Remenyi (2005) and Yanow and Schwartz-Shea (2006).

The central research question we explore is: what may be the key influences or factors which might be likely to increase the probability of success for entrepreneurship (or entrepreneurial activity) by FIEs and by domestic Chinese firms? We break this down into two subsidiary objectives. Is there a separate and distinct phenomenon of Chinese entrepreneurship? Finding there is not in reality such a distinct phenomenon, the task becomes one of identifying a key set of necessary conditions (pointing towards but probably not arriving at a sufficient set) in the China context to support such entrepreneurial activity as is occurring.

Given this to be the character of the piece, it is useful to pause here to reflect why research such as this is useful and important, given that the bulk of research published in the business subject area conforms to some variant of the empirical positivist approach, see Collis and Hussey (2003) for details of that approach. Our view is that research of the kind we present here is undoubtedly worth doing for two key reasons.

The first reason is that we are casting our net wide, necessarily so, to see what inputs, from whatever sub-literatures, may be helpful to us. This means in turn that to make sense of things we need so summarise and try to draw conclusions, as indeed we did in the preceding section. Such surveying and précising activity is useful because it helps to develop a more holistic picture of events. Thus we looked at what some may regard as 'different literatures' relating to the broad topic of entrepreneurship. Our argument is that such sub-strands (technological entrepreneurship, entrepreneurial mindset, small business entrepreneurship, entrepreneurship in transition contexts, entrepreneurial learning etc) are, as stated, just parts of what should sensibly be regarded as a single literature (or interdisciplinary literature) aimed at understanding entrepreneurship. This interdisciplinary approach has been wellargued by a number of actors in the field (Dowling et al 2005; Song, 2007). Indeed, Sexton and Landström (2000), the authors of the Handbook of Entrepreneurship, go so far as to refer to entrepreneurship as being "un-disciplinary" rather than an "interdisciplinary" field of study. Smallbone and Welter (2006, p.193) refer to entrepreneurship as, "a multidimensional concept that can be analysed at different levels."

The second reason is that the conclusions we are able to draw and the recommendations emanating thence are necessarily directly applicable for both companies on the one hand and government, who should logically wish to facilitate the good operation of those companies, on the other hand. As the renowned, heterodox economist E.F. Schumacher put it, BBC (2016), "an ounce of practice is generally worth more than a ton of theory."

\section{Facilitating, contextual factors for entrepreneurship}

If the difference between entrepreneurship as experienced in China and say the EU centres on the contextual factors experienced, then the task should be to propose what can be done to help with the context in China. We shall address the four key external elements noted above. Handling this set of four factors may not deliver a sufficient set of favourable elements but it should certainly provide a necessary set, which would be a positive step.

However, we first reflect briefly on culture's possible impact on entrepreneurship in China, not because it will necessarily be a facilitating factor but because it is part of the scene within 
which other factors are allowed to flourish or are inhibited. In the third section, on the nature of entrepreneurship, we noted that so-called entrepreneurial mindset (EM), is a necessary internal factor if there is to be successful entrepreneurial activity in a firm, albeit an excessive zeal for can the more go-getting aspects of that mindset may in some circumstances become a negative influence - managers may, in their enthusiasm for change, fail to see that enough is enough in a particular case. Wang (2012) speculates that some aspects of Chinese culture may be inhibiting factors when firms seek to be entrepreneurial. He suggests that some Chinese personality traits may not be consonant with successful entrepreneurship and that some Chinese, socio-cultural factors are unfavourable to entrepreneurship, or, put another way, these negative components of Chinese cultural mores detract from the overall EM which is required. In particular, he proposes that these negative factors may include a tendency to discourage pro-activeness and an unwillingness to verbalise views held in formal settings because of concerns regarding the estimation of self-image of others. From one's own experience, this latter point is plausible. We have found that some Chinese are unwilling to speak out even when they disagree or feel they have better ideas to offer if 'one' is perceived to be their 'superior' in status terms. The inhibiting aspect of Chinese culture is supported by the work of Watkins-Mathys (2015) on entrepreneurial learning within the Chinese business context.

For completeness and balance, we note that Wang (2012) does also suggest that some aspects of Chinese culture may also be helpful in the arena of entrepreneurial activity, especially where firms are of relatively modest size; namely, family involvement and financial support. We pick up the debate about financing in more detail below.

We now look at the four external factors identified in the order listed. One way of looking at these factors is through the lens of institutional theory, North (1990), Zucker (1987) - an approach adopted by Welter and Smallbone in their studies on entrepreneurship in emerging East-European countries (Smallbone and Welter, 2006; Smallbone et al, 2014). The factors are of themselves, or the resolutions of associated problems are, basically elements of the institutional setting.

\subsection{Networking}

Networking, or its associated networks, can relate to several aspects of business. First there is the issue raised by an interviewee for the Watkins-Mathys and Foster (2006) study. He stated that one simply cannot get public sector work, as a contractor, in China unless one has connections in the relevant level of government bureaucracy. He may well be right - one hears such thoughts around - but if business is to be conducted fairly and transparently this is clearly unacceptable. Contracts should be let on the basis of competence and price (value for money). Hence if entrepreneurs are to be encouraged across both public and private sectors of the PRC economy, government must change the climate and outlaw the nepotistic awarding of contracts.

Table 3 below shows the perceived importance, in rank order, of networks for various functions of business development as rated by managers of SMEs in the IT-software industry in China. 
Table 3 - The role of Networks in establishing/developing business

\begin{tabular}{lcc}
\hline Aspects affected & Mean rating & Std Dev \\
\hline Garnering business & 3.70 & 1.30 \\
opportunities & 3.25 & 1.36 \\
Initial establishment & 2.75 & 1.43 \\
Gaining initial capital & 2.74 & 1.43 \\
Finding good staff & 2.62 & 1.33 \\
Gaining access to further funds & 1.83 & 1.30 \\
Other
\end{tabular}

Source: Cao et al (2014, p34), items scored using 5-pt Likert scale

The first item listed covers the garnering of opportunities, or contracts, in the private as well as the public sector. Especially for start-ups, it is not surprising that working with known contacts will be a good place to start which is fine. However, the point made earlier in relation to public sector contracts remains, especially given Xi Jinping's anti-corruption drive over the past four years or more.

As we shall see in the next subsection, it is not surprising that gaining access to funds is not more highly rated. This is because, quite simply, it is very hard for smaller firms to access capital not least because systems to make provision of such access are deficient. Interestingly, Guo et al (2012) found rather differently; their analysis revealed inter alia, for their sample at least, "the important role played by networks and government grants in building capabilities to help new ventures obtain venture capital." Perhaps this simply highlights the complex and varied picture which may be found in a large, complex economy such as China's now is.

Overall, Cao's data relate to SMEs in one particular industry sector but it is an HAV sector and there is no obvious reason to suppose that similar situations will not obtain for firms in other industry sectors.

\subsection{Availability of venture capital}

The problem here is that $\mathrm{VC}$ as it would be understood in the U.S. and European markets is not widely available in China. The problem is even greater for SMEs, see Cao et al (2014). Indeed, even if we use the term VC more loosely to mean both VC as it would normally be understood and also long term and working capital available from other sources including commercial banks, accessibility is still a problem in China for SMEs. The phenomenon of progress impeded by a lack of available finance is supported by Zhang and Si (2008) and Ahlstrom and Ding (2014). It was for this reason that Cao et al (2014) found that, especially initially, many of their SME subjects relied on their own funds or those obtained from relatives and friends - this resonates with the point earlier from Wang (2012). It is worth noting however that $\mathrm{Au}$ and Kwan (2009) present a contrary view. They examined initial capital formation in Chinese start-ups, using two data clusters in Hong Kong and mainland China. They suggest that, contrary to what they assert to be the prevailing view of Chinese family business, family funding is not the automatic position, unless keeping things in the family a) has lower transaction costs than the alternative and b) there are low levels of associated interference by the family. 
When seeking such finances as may be available, presenting a coherent business plan is highly desirable and often essential, see e.g. Watts and Wardle (2006). Wu et al (2010) (using a multi-industry sample) emphasised the need to develop strategic planning models tailored to the promotion of technological development in China, in part as an aid to accessing funding by establishing business credibility.

MNCs who make investments in China are of course better placed than their local competitors, especially the smaller ones, in that they have the capability to access venture capital from the international markets to underwrite the more entrepreneurial elements of their activities. The moral would seem to be that developing a VC market in China, which is prepared inter alia to consider SME applications, is a necessary step for the PRC government if it wishes to support entrepreneurship and indeed intrapreneurship in HAV industries.

\subsection{Availability of business savvy employees}

The subject of many conversations we have held over the past decade or more with business people in China, be they Chinese or ex-patriates, comes to the same point. There is a great lack of educated people who have the capability and/or willingness to think creatively and to take responsibility for decisions they may make, and as Dimov (2010) emphasises human capital is an essential element of the entrepreneurial process anywhere. This applies both at the level of the competent technician for the shop floor and for management positions. The problem is that especially in the latter category this is precisely what is required to man up the entrepreneurial firms of China. Of course there are some such people but just not enough. Because, as we suggested earlier, this can be seen as an institutional issue, response by the relevant authorities is required. This could be the Chinese education authorities or even some higher authority, perhaps as high as the Central Committee.

This issue should not be confused with the reported growth of interest in start-ups in China, Bradshaw (2014). No one denies that there is such growth but if start-ups are to grow from mere acorns to be great oak trees then they will need people as they grow, just as do large companies - be they MNCs or domestic Chinese firms - to man their life sustaining, intrapreneurial activity. As we wrote above, at the moment there is a paucity of the right kind of talent.

One of the key reasons for the paucity of people with managerial potential and entrepreneurial spirit is the role played by the universities. They turn out lots of graduates with high grades who seem incapable of creative thought. Why? They are taught facts and how to use them to pass exams: they are not encouraged to learn to think and problem solve, see Cao et al (2014) and Zhou and Peng (2008). Moreover, regarding the possibility of the development of enterprising firms within the university, Zhou and Peng (2008, p.637) estimate that problems are set to persist for a while yet: in their words, "a few elite universities will become entrepreneurial universities within 10-20 years."

This general problem is why it sometimes happens that young men and women who don't have contacts nor even the very best grades in university but who have studied abroad get surprising offers. An example would be the young BA graduate - a nice fellow but no genius - who studied at an ex-polytechnic in London. He found himself sitting on a train talking to his neighbour soon after his return to China. Simply on the basis that he had a few ideas and could present himself positively his neighbour gave him a card and told him to call him when 
he was in Shanghai. He was hired by Disney (China) shortly thereafter, since that was who his interlocutor worked for in a senior position.

Another possible source of better Business, even entrepreneurially, prepared graduates from which China's new firms may recruit are the Business Schools of foreign universities' campuses in China. These include Nottingham University at Ningbo, CEIBS (China Europe International Business School) in the Pudong area of Shanghai and Liverpool Xian Jiaotong University (LXJTU), a joint venture between the two parents located in Suzhou. All of these universities run MBA programmes and would certainly claim to produce well prepared graduates exposed to the realities of business decision making, using tools such as case study analysis and practical projects. While they may well produce more business savvy graduates than many domestic Chinese business schools, there may still be a 'reality gap', as is frankly true of US and European schools too. Of the three mentioned CEIBS would probably view itself as the most prestigious but it is an unfortunate fact that some of its supposedly high profile faculty members have a great lack of hands on commercial experience. This applies to some of its foreign faculty.

On the other side of the coin, a survey by Wilkins et al (2018) produced some interesting results on the issue of why Chinese students signed up for MBA programmes. They found that students' desire to acquire knowledge and skills was the strongest motivator among respondents: this contrasted with their prior expectation that prestige and networking might be the big drivers.

This issue is one which the Chinese authorities could deal with if they have the political will but it is clear that only a dramatic change of thinking as to what constitutes effective education can solve the current shortage of business literate graduates and trained technicians who also have some conception of creative thinking.

\subsection{Regulatory issues}

Two key factors which may have a negative impact on entrepreneurial development in China are the poor protection of intellectual property rights (IPR) in China and perceptions that regulations may be unevenly applied to the detriment of FIEs. The first is widely reported (see for example Dimitrov (2007) and Tian (2007)) and can affect both PRC owned firms and FIEs. Nevertheless, FIEs, rightly or wrongly, fear that they are particularly at risk. This was the substance of the complaint made by Jurgen Hambrecht, the chairman of BASF, and Peter Loscher, the chief executive of Siemens when, in July 2010, along with Germany's Chancellor Merkel, they attended a meeting with the then PRC Prime Minister, Wen Jiabao, Dean (2010). They argued that in essence foreign companies were being pressurised to transfer valuable intellectual property in order to be allowed to gain market access. $\mathrm{Mr}$ Hambrecht was reported to have said that, "the "forced disclosure of know-how' in order to do business in China does not exactly correspond to our views of a partnership."

Moving on to wider 'anti-foreign' policies, as found on the ground even if not present in theory, Dean (2010) and Grant (2010) both report that Mr Loscher reiterated widespread foreign complaints about procurement rules that China has drafted, which could give a major advantage to companies with 'indigenous innovation'. He also noted that foreign companies feared that such policy could shut them out of very high-value government contracts. Such bias is of course directly contradictory to the WTO rules to which China signed up in December 2001. 
Another example of perverse use of regulations is to be found in the case of Kingfisher and their travails with 'Regulation 17' and their vendor buying agreements (VBAs), Foster and Tseng (2012). Indeed such was the perversity of their position that it gave rise to the question "when is a legally sound contract not 'acceptable' in China?" The answer seemed to be "when suppliers want a more favourable deal and the buyer is an FIE"! Very recently Kingfisher decided it had had enough of struggling with the business environment in the PRC and sold off its Chinese DIY business to Chinese retailer, Wumei Holdings, Kingfisher (2016).

A final problem concerning the law and regulatory environment is the variable application and interpretation of the law generally in China. Quite simply, there is a lack of consistency in the outcomes of laws, see e.g. Foster (1997), Kwok (2009). Part of the problem is that what would be seen by western lawyers as loose drafting of legislation means that laws once enacted are almost inevitably subject to variable interpretation across the 31 provinces which comprise the PRC.

Here again the issue is in principle tractable but would require both improved drafting of legislation and a move to genuinely impartial application of the law. Such impartiality may be both in the sense of being independent of any overt political pressure and also in the sense that the courts across the different provinces of the huge country which is China would arrive at similar conclusions given similar evidence.

\section{Conclusion and recommendations}

At the outset the question we posed was what may be the key influences or factors which might be likely to increase the probability of success for entrepreneurial activity by FIEs and also by domestic Chinese firms. Our initial step was to examine the very nature of entrepreneurship and debate the possibility of there being a somehow unique and different phenomenon which could be called Chinese entrepreneurship. Our conclusion is that there is in reality no such different and separate phenomenon even if the phrase is to be found quite often in the titles of papers concerning Chinese business. What certainly is different and specific to China is the context within which would-be entrepreneurs in China operate, be they FIEs or domestic Chinese firms. Hence the question we sought to discuss here was what may be the key influences or factors which might be likely to increase the probability of success for entrepreneurial activity in China.

Moving on to examine that context, we identified four, key, external factors which play an important role in the Chinese business entrepreneurship context and with which would be entrepreneurs in China must cope: namely, networks, access to venture capital (widely construed), availability of business savvy employees and the regulatory environment (both laws and regulatory pronouncements for business). These four widely drawn factors are therefore a set of necessary conditions for the effective progress of entrepreneurship in China. We freely admit that they are unlikely to be a sufficient set but they form a working basis from which to work outwards towards a more complete answer.

Another, fifth factor is Chinese culture. We found evidence suggesting that there may be negative effects experienced in relation to such culture albeit with some affirmative aspects. One important example of such negativity would be the inability of a more senior person to 
accept advice from a junior even when that junior is showing precisely the positivity and imagination which effective delivery of entrepreneurial activity requires. In other words, the senior's perceived need for recognition of their status (Bond, 1991) may be an impediment to the overall good of the business.

Turning to the four main, external factors, networks can be an important and positive force for good. The caveat is that the negative side of the guanxi system in China, where benefits are derived in a manner which is unfair to 'outsiders' at best or at worst is downright corrupt, requires remedial action. In the PRC context, it seems likely that only the central government has the clout to deliver such reform and ensure it is even-handed in its application.

Venture capital is in limited supply in China and for small firms even more routine sources of finance (bank loans etc) may be hard to come by. This seems to be an area where government really should be able to help. On the one hand they have a major presence in the commercial banking sector and as such have it within their gift to act more affirmatively for good quality smaller businesses. Of course not all SMEs will be a good proposition in lending terms: this is true worldwide. The trick is to sort the chaff from the wheat and to support the 'wheat'. Further, one can envisage a perhaps modest scale, government operated VC body whose target market would be HAV SMEs. As noted before, FIEs are less constrained because they have access to international sources of finance.

Again with the issue of business savvy employees being in short supply, the government (at national and provincial levels) has a role to play. Put simply the education system needs reform to produce diplomates and graduates who can think for themselves and problem solve, not just pass exams for which they have been rehearsed. This of course is easy to say but much harder to deliver: it requires a fundamental change of mindset on the part of those in authority.

Then we have the legal and business regulatory frameworks. Put simply the laws probably need improvement in terms of being better and more tightly drafted, leaving less scope for regional or vicarious interpretation. Even if quality drafting is evident in laws and regulations, there needs to be equitable oversight of these laws and regulations. This is especially true for FIEs since, as outlined before, there is evidence that major foreign investors feel themselves to be overtly discriminated against, and in some cases to be subject to unfair and improper demands as a pre-requisite for the grant of permission for their for their investments. As explained in the Introduction, the PRC government is on record as stating that it continues to support and seeks FDI especially in HAV sectors.

Of course not everything is just down to government but it is interesting to note that we have identified a role for them relative to each of our four necessary factors. Other actors will also have a role to play. For example, China's domestic banks could enhance their credit assessment techniques in order to locate those entrepreneurial businesses lending to whom would be more likely to be successful. Universities could adopt measures for internal reform and so on.

If the changes we have proposed, including changes requiring action by the PRC government as a facilitator, were to be implemented then the positive end-state at which one might arrive (delivery of a set of necessary positive conditions) would be as shown in Figure 1. 
Overall, the necessary, external factors identified, mediated by the influence of Chinese culture, must also be complemented by the presence within a firm of an entrepreneurial mindset, if entrepreneurship is indeed to flourish.

An interesting question asked of us by a referee was: "how different might $\mathrm{CE}$ be in 'overseas Chinese' contexts - say, Taiwan or Singapore, both of which are Chinese-majority states?" Arguing on an a priori basis, our first order answer would have to be 'rather a lot' because the regulatory, social and industry structural settings vary sharply between those overseas settings and the PRC and we concluded, as noted earlier, that there is not in reality a separate and distinct phenomenon of CE. However, what has been widely suggested is that the overseas Chinese are key actors in the driving of many regional economies in East and SouthEast Asia, see for example Carney and Gedajlovic (2002), Redding (1990). Redding (1990) famously described the key driving influence of the Chinese diaspora as 'Confucian dynamism' and it is certainly true that many major corporations in countries in S.E. Asia such as Thailand and Malaysia are owned or directed by Chinese Thais or Chinese Malaysians.

Figure 1 An improved setting for Chinese entrepreneurial activity 


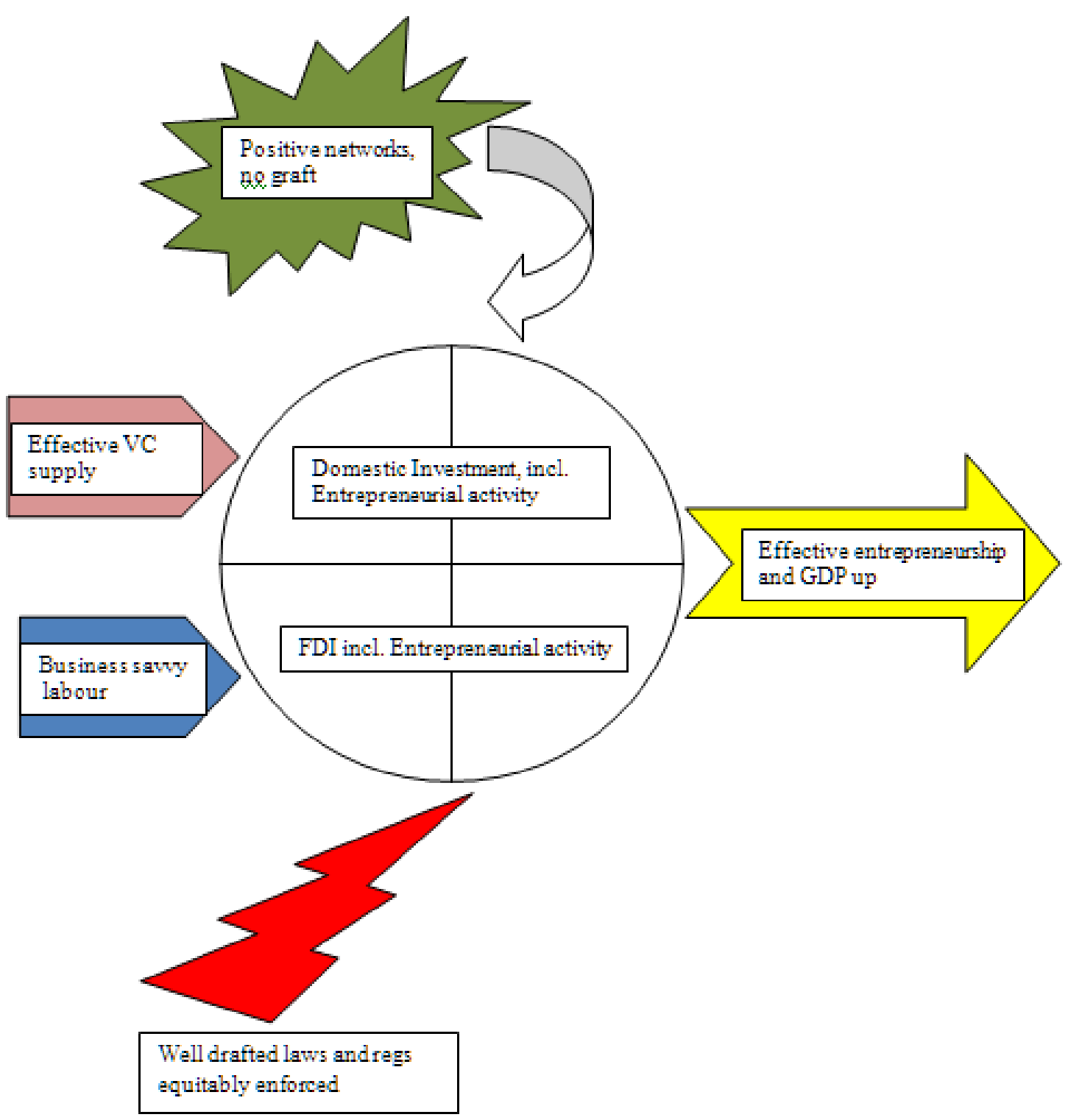




\section{References}

Ahlstrom, D. and Ding, Z-J. (2014), 'Entrepreneurship in China: an overview', International Small Business Journal, Vol. 32, No. 6, pp.610-618.

Antoncic, B. and Hisrich, R.D. (2001) 'Intrapreneurship: construct refinement and crosscultural validation', Journal of Business Venturing, Vol. 16, No.5, pp.495-527.

Au, K. and Kwan, H.K. (2009) 'Start-up capital and Chinese entrepreneurs: the role of family', Entrepreneurship Theory and Practice, Vol. 33, No. 4, pp.889-908.

BBC (2016), 'E.F. Schumacher: is small the next big?', BBC Radio 4, $9^{\text {th }}$ May, 2016, 8 p.m.

Bond, M.H. (1991) Beyond the Chinese Face, Oxford U.P, New York.

Bradshaw, D. (2014) 'The rise of China's entrepreneurial spirit', Financial Times, $7^{\text {th }}$ December. Available on-line at: https:/www.ft.com/content/962a905a-70a3-11e4-912900144feabdc0\#ixzz4LXaIaToZ

Bygrave, W. (2004) 'The entrepreneurial process', in: Bygrave, W. and Zarcharakis, A. (Eds.), The Portable MBA in Entrepreneurship, $3^{\text {rd }}$ ed., Hoboken: J.Wiley \& Sons, pp.1-28.

Cao, J-H. (2009) The Role of Entrepreneurship in China's SMEs in Effecting Technology Transfer from Local Universities. Unpublished Doctoral Thesis, Kingston Business School.

Cao, J-H., Foster, M.J. and Watkins-Mathys, L. (2014) 'IT-Software SMEs in China, technology transfer from Universities and entrepreneurship, a successful nexus?', Frontiers of Business Research in China, Vol. 8, No. 1, pp.18-48

Cantillon, R. (2010) An Essay on Economic Theory (an English translation of Cantillon's 'Essai sur la Nature du Commerce en Général' by Chantal Saucier), Ludwig von Mises Institute, Auburn, AL.

Carlisle, E. and Flynn, D. (2005) 'Small business survival in China: guanxi, legitimacy and social capital', Journal of Developmental Entrepreneurship, Vol. 10, No. 1, pp.79-96.

Carney, M. and Gedajlovic, E. (2002) 'The co-evolution of institutional environments and organizational strategies: the rise of family business groups in the ASEAN region', Organization Studies, Vol. 23, No. 1, pp.1-29.

Concise Oxford Dictionary (C.O.D.) (1976), $5^{\text {th }}$ ed., Oxford U.P, Oxford.

Collis, J. and Hussey, R. (2003), Business Research: a Practical Guide for Postgraduate and Undergraduate Students, $2^{\text {nd }}$ ed., Palgrave, Basingstoke.

Cunningham, J.B. and Lischeron, J (1991) 'Defining entrepreneurship', Journal of Small Business Management, Vol. 29, No. 1, pp.45-61. 
Dean, J. (2010) 'Foreign business has it tough in China, BASF and Siemens tell China', The Wall Street Journal, $19^{\text {th }}$ July. Available at: https://www.wsj.com/articles/SB100014240 52748704196404575376010186980750. Accessed 24th October 2014.

Dimitrov, M.K. (2007) Piracy and the State: The Politics of Intellectual Property Rights in China, Cambridge U.P., New York.

Dimov, D. (2010) 'Nascent entrepreneurs and venture emergence, opportunity confidence, human capital and early planning', Journal of Management Studies, Vol. 47, No. 6, pp.11231153.

Dowling, M., Schmude, J and zu Knyphausen-Aufsess, D. (2005) Interdisciplinary Research in Entrepreneurship, Die Deutsche Bibliothek, Münster.

Drejer, A., Christensen, K.S. and Ulhøi, J.P. (2004) 'Understanding intrapreneurship by means of state-of-the-art knowledge management and organisational learning theory', International Journal of Management and Enterprise Development, Vol. 1, No. 2, pp.102119.

Foster, M.J. (1997) 'Straight Business Chinese Style', Asian Case Research Journal, Vol. 1, No. 1, pp.43-51.

Foster, M.J. (2014) 'Foreign Direct Investment in China', in: Oxford Bibliographies in Chinese Studies, Ed. Tim Wright. New York: Oxford University Press.(on-line), published $28^{\text {th }}$ October 2014. DOI: 10.1093/OBO/9780199920082-0109

Foster, M.J. and Tseng, C.S. (2012) 'Kingfisher attacks the China market', Frontiers of Business Research in China, Vol. 6, No. 1, pp.156-168

Foster, M.J. and Tseng, C.S. (2014) 'Foreign Investment in China booms but collaborating with PRC companies can still be problematic', Proceedings of AIB S.E. Asia Regional Conference, Macau, $7^{\text {th }}-9^{\text {th }}$ December 2014 (paper number 38).

Foster, M.J. (2015) 'MNCs face renewed problems in 21st Century China', Paper S07 at $2^{\text {nd }}$ Frontiers of Business Research in China International Symposium, Renmin University, Beijing, 22 $2^{\text {nd }}-23^{\text {rd }}$ May 2015.

Gartner, W. (1988) 'Who is an entrepreneur? Is this the wrong question?', American Journal of Small Business, Vol. 12, No1, pp.11-31.

Gilchrist, Karen (2018), 'Here are the 10 wealthiest people in China - a country leading the way for self-made billionaires', CNBC MAKE IT, $20^{\text {th }}$ February 2018. Available at:

https://www.cnbc.com/2018/02/20/self-made-billionaires-chinas-10-richest-billionaires.html

Grant, C. (2010) 'Is China being beastly to foreign investors?', Insight from Centre for European Reform, 30 $0^{\text {th }}$ July 2010. Available at: https://www.cer.eu/insights/china-beingbeastly-foreign-investors. Accessed 15th January 2019. 
Guo, T, Hong, J., Zhao, D., Wu, Y. and Fan, J. (2012) 'The incubators, venture capital, and new ventures in China', International Journal of Innovation, Management and Technology, Vol. 3, No. 4, pp.358-362.

Haynie, M. and Shepherd, D.A. (2009) 'A measure of adaptive cognition for entrepreneurship research', Entrepreneurship Theory and Practice, Vol. 33, No. 3, pp.695714.

Herbert, R. F. and Link, A. N. (1988) The Entrepreneur: Mainstream Views and Radical Critiques, $2^{\text {nd }}$ ed., Praeger, New York.

Huang, Y-S. (2010) 'Entrepreneurship in China', World Financial Review, $28^{\text {th }}$ December. Available at http://www.worldfinancialreview.com/?p=2782

Kier, A.S., McMullen, J.S. and Kuratko, D.S. (2014) 'Trapped by the entrepreneurial mindset? An examination of regulatory focus and escalation of commitment in entrepreneurial action', Frontiers of Entrepreneurship Research, Vol. 34, No. 5, article 3 (15pp). Available at: http://digitalknowledge.babson.edu/fer/vol34/iss5/3.

Kingfisher (2016) Kingfisher Press Release for Final Results for year ending 31 January 2016, $23^{\text {rd }}$ March 2016.

Klepper, S. and Sleeper, S. (2005) 'Entry by spinoffs', Management Science, Vol. 51, No. 8, pp.1291-1306.

Knight, F.H. (1921) Risk, Uncertainty, and Profit, Hart, Schaffner \& Marx, Houghton Mifflin Co., Boston, MA.

Kwok, W-Y. Vivian (2009) 'Danone gives up China fight', Forbes, $30^{\text {th }}$ Sept. Accessible at http://www.forbes.com/2009/09/30/danone-wahaha-dispute-markets-business-trademark.html

Kshetri, N. (2007) 'Institutional changes affecting entrepreneurship in China', Journal of Developmental Entrepreneurship, Vol. 12, No. 4, pp.415-432.

Li, J. and Matlay, H. (2006) 'Chinese entrepreneurship and small business development: an overview and research agenda', Journal of Small Business and Enterprise Development, Vol.13, No. 2, pp.248-262.

Li, J., Young, M.N. and Tang, G. (2012) 'The development of entrepreneurship in Chinese communities: an organisational symbiosis perspective', Asia Pacific Journal of Management, Vol. 29, No. 2, pp.367-385.

Li, J-B. (2013) 'FDI grows steadily amid reform drive', China Daily - Asian Weekly, 22-28 November, p.12.

McGrath, R.G. and MacMillan, I. (2000) The Entrepreneurial Mindset: Strategies for Continuously Creating Opportunity in an Age of Uncertainty, Harvard Business School Press, Boston. 
North, D.C. (1990) Institutions, Institutional Change and Economic Performance, Cambridge U.P., Cambridge.

Olsson, O. and Frey, B.S. (2002) 'Entrepreneurship as recombinant growth', Small Business Economics Vol. 19, No.2, pp.69-80.

Petti, C. and Zhang, S. (2011) 'Factors influencing technology entrepreneurship capabilities; Towards an integrated research framework four Chinese enterprises', Journal of Technology Management in China, Vol. 6, No. 1, pp.7-25

Porter, M. (1998) 'Clusters and the new economics of competition', Harvard Business Review, Nov-Dec Issue, pp.77-90.

Redding, S.G. (1990) The Spirit of Chinese Capitalism. Walter de Gruyter, Berlin.

Remenyi, D. (2005), 'Tell me a story - a way to knowledge', The Electronic Journal of Business Research Methodology, Vol. 3, No. 2, pp.133-140. (available at www.ejbrm.com)

Reynolds, P., Camp, S., Bygrave W., Autio E. and Hay, M. (2002) Global Entrepreneurship Monitor 2001, Executive Report, Babson College and London Business School, Bason Park/London.

Say, J-P. (1850) A Treatise on Political Economy; or The Production, Distribution and Consumption of Wealth (translated from the $4^{\text {th }}$ ed. in French by C.R. Prinsep), J.J. Lippincott \& Co., Philadelphia.

Schumpeter, J. (1934) The Theory of Economic Development. Harvard University Press, Cambridge, MA.

Schumpeter, J. (1942) Capitalism, Socialism and Democracy, Harper \& Row, New York.

Sexton, D.L. and Landström, H. (2000) The Blackwell Handbook of Entrepreneurship, Blackwell, Oxford.

Shane, S. and Venkataraman, S. (2000) 'The promise of entrepreneurship as a field of research', Academy of Management Research, Vol. 25, No. 1, pp.217-226.

Smallbone, D. and Welter, F. (2006) 'Conceptualising entrepreneurship in a transition context', International Journal of Entrepreneurship and Small Business, Vol. 3, No. 2, pp.190-206.

Smallbone, D., Welter, F. and Ateljevic, J. (2014) 'Entrepreneurship in emerging market economies: Contemporary issues and perspectives', International Small Business Journal: Researching, Vol. 32, No. 2, pp.113-116.

Song, Yoo-Seong (2007) 'Engineering Entrepreneurship', in: Literature Search Strategies for Interdisciplinary Research: A Sourcebook for Scientists and Engineers, Ed. Linda G. Ackerson. Maryland: Scarecrow Press, Inc. DOI: 10.1080/00049670.2008.10722522 
Tian, X-W. (2007) Managing International Business in China, Ch.10, Cambridge U.P., Cambridge.

Tsang, E.W.K. (1998) 'Can guanxi be a source of sustained competitive advantage for doing business in China?', Academy of Management Perspectives, Vol. 12, No. 2, pp.64-73.

Tseng, C.S. and Foster, M.J. (2006) 'A flexible response to Guo Qing: Experience of three MNCs entering restricted sectors of the PRC economy', Asian Business and Management, Vol. 5, No. 3, pp. 315-332.

Volberda, H.W., Morgan, R.E., Reinmoeller, P., Hitt, M.A., Ireland, R.D. and Hoskisson, R.E (2011). Strategic Management, Competitiveness and Globalisation: Concepts and Cases, Cengage Learning, Andover.

Wang, Y. and Lu, L. (2007) 'Knowledge transfer through effective university-industry interactions: Empirical experience from China', Journal of Technology Management in China, Vol. 2, No. 2, pp.128-131.

Wang, R-X. (2012) 'Chinese culture and its potential influence on entrepreneurship', International Business Research, Vol. 5, No. 10, pp.76-90.

Watkins-Mathys, L. and Foster, M.J. (2006) 'Entrepreneurship: the still missing ingredient in China’s STIPs?', Entrepreneurship and Regional Development, Vol. 18, No. 3, pp.249-274.

Watkins-Mathys, L. (2015) 'Entrepreneurial learning in the Chinese business context', in: Rae, D. and Wang, C.L., Entrepreneurial Learning: New Perspectives in Research Education, Learning and Practice, Routledge, London. Available at: https://www.routledge.com/Entrepreneurial-Learning-New-Perspectives-in-ResearchEducation-and-Practice/Rae-Wang/p/book/9780415723244

Watts, H. D. and Wardle, P. (2006) 'Owner-managers' business planning in the small firm', International Small Business Journal, Vol. 24, No. 5, pp.496-514.

Wilkins, S., He, L., Zhu, Li. And Elmoshnib, Md. (2018), 'The resilience of the MBA in emerging economies: student motivations for wanting an MBA in China and the United Arab Emirates', Journal of Higher Education Policy and Management, Vol. 40, No. 3, pp.256271.

Wu, W-W., Liang, D-P., Yu, B. and Yang, Y. (2010) 'Strategic planning for management of technology of China's high technology enterprises', Journal of Technology Management in China, Vol. 5, No.1, pp.6-25.

Yanow, D. and Schwartz-Shea, P. (Eds.) (2006) Interpretation and Method: Empirical Research Methods and the Interpretive Turn, M.E. Sharpe, New York.

$\mathrm{Yu}$, J. and Stough, R.R. (2006) 'The determinants of entrepreneurship development in China', International Journal of Management and Education, Vol. 3, No. 1/2, pp.30-52.

Zhang, G., Pen, X. and Li, J. (2008) 'Technological entrepreneurship and policy environment: a case of China', Journal of Small Business and Enterprise Development, Vol. 15 , No. 4, pp.733-751. 
Zhang, Y-F. and Si, C-L. (2008) 'The impacts of external factors on the growth of Chinese entrepreneurial enterprises: an empirical study', Journal of Small Business and Enterprise Development, Vol. 15, No. 4, pp.689-703.

Zhou, C.Y. and Peng, X-M. (2008) 'The entrepreneurial university in China: nonlinear paths', Science and Public Policy, Vol. 35, No. 9, 637-646.

Zucker, L.G. (1987) 'Institutional theories of organisation', Annual Review of Sociology, Vol. 13, pp.443-464. 